\title{
ANALISIS PENERAPAN WAKAF POLIS DI ASURANSI SYARIAH
}

\author{
Nur Dinah Fauziah; Tanto Fatkhurrozi \\ Institut Pesantren KH. Abdul Chalim Mojokerto \\ e-mail:dina.fau@gmail.com; tanto.rozi@gmail.com
}

\begin{abstract}
Economic development in Indonesia has led to the new various products and also the sharia economic development in Indonesia, although it is still relatively young, but the sharia economy continues to thrive with various types of products that can increase the economy. The development of insurance in Indonesia is the form of variation that is able to make Islamic insurance can remain in financial products that are still in demanded by the public, also Waqf polis insurance is a waqf plan by legally inheriting a portion of the asset ownership by waqif when the person dies but can still enjoy the benefits of the assets represented as long as the waqif lives up to the potential and benefits of waqf and its management is productively waqf from the insurance side especially from sharia insurance with the combination of waqf and insurance. This research belongs to the type of literature study research by looking for theoretical references that are relevant to the cases or problems founded and also from several previous studies and from the internet. Productive waqf insurance is successfully integrated so that Indonesia's economy growth through waqf can be realized immediately.
\end{abstract}

Keywords: waqf, sharia insurance, polis wills

\section{Pendahuluan}

Perkembangan ekonomi di Indonesia memunculkan berbagai jenis produk baru dan bervariasi, pun juga dengan perkembangan ekonomi syariah di Indonesia walaupun tergolong baru masih muda namun ekonomi syariah terus berkembang dengan bebagai macam produk yang mampu meningkatkan perekonomian. Lembaga keuangan syariah dibagi menjadi dua, yaitu lembaga keuangan syariah bank dan lembaga keuangan syariah non bank. Lembaga keuangan non bank adalah lembaga keuangan yang lebih terfokus kepada bidang penyaluran dana dan masing-masing lembaga keuangan mempunyai ciri-ciri usahanya sendiri. Adapun jenis lembaga keuangan non bank yang ada di Indonesia saat ini antara lain lembaga keuangan yang kegiatan usahanya bersifat kontraktual, lembaga keuangan investasi dan perusahaan modal ventura dan perusahaan pembiayaan yang menawarkan jasa pembiayaan sewa guna usaha, anjak piutang, pembiayaan konsumen dan kartu kredit.

Salah satu lembaga keuangan syariah non bank yang mengalami perkembangan pesat adalah asuransi syariah, Data Statistik IKNB Syariah menyebutkan bahwa perkembangan industri asuransi umum syariah pada tahun 2019 tercatat pertumbuhan positif total aset yang dibukukan sebesar 5.903 triliun rupiah dari tahun sebelumnya dengan kenaikan sebesar 5,02 persen. ${ }^{1}$

\footnotetext{
${ }^{1}$ https://www.industry.co.id/read/62257/perkembangan-industri-asuransi-syariah-membanggakan-di-tahun-2019 diakses pada 15 Februari 2020
} 
Berdasarkan fatwa DSN-MUI Nomor 21/DSNMUI/X/2001, asuransi syariah (ta'min, takäful, tadämun) adalah usaha saling melindungi dan tolong menolong di antara sejumlah orang atau pihak melalui investasi dalam bentuk aset dan atau tabarru' memberikan pola pengembalian untuk menghadapi risiko tertentu melalui akad (perikatan) yang sesuai dengan syariah. $^{2}$

Asuransi bagi masyarakat modern dianggap sebagai kebutuhan untuk menjamin perlindungan diri dan harta benda dari musibah yang akan datang. Kontrak asuransi modern secara umum memiliki kesinambungan sejarah dengan praktek pinjam meminjam yang pernah dilakukan pada zaman Yunani kuno. ${ }^{3}$ Semua asuransi baik pada masa Yunani kuno maupun asuransi pada masa sekarang pada intinya memiliki tujuan yang sama, yaitu memberikan perlindungan atas semua jenis risiko yang mungkin menimpa manusia di masa yang akan datang.

Sebagian orang terlibat dalam praktek asuransi dengan motif untuk mengalihkan beban atas kemungkinan kerugian kepada pihak lain yang bersedia mengambil alih risiko. Prinsip asuransi dinilai sangat baik bagi kebutuhan manusia saat ini. Jika dikulik dari syariah asuransi memang banyak menimbulkan pro dan kontra sehingga masih banyak yang ragu namun seiring dengan banyaknya pengetahuan tentang asuransi syariah banyak masyarakat yang mulai mempertimbangkanya. Berbagai produk yang ada pun bervariasi di tengah isu asuransi Jiwasraya yang diterpa beberapa masalah memang membuat masyarakat ragu untuk berasuransi dan pemerintah yang telah menaikkan iuran BPJS bisa menjadi tanggapan dan hambatan serius bagi berkembangnya asuransi yang ada di Indonesia, namun bentuk variasi yang ada mampu membuat asuransi syariah bisa tetap berada di antara produk-produk keuangan yang masih diminati masyarakat, begitu juga wakaf wasiat polis asuransi syariah.

Wakaf wasiat adalah suatu perencanaan wakaf dengan mewasiatkan secara legal sebagian dari kepemilikan aset wäqif ketika yang bersangkutan meninggal dunia namun tetap dapat menikmati manfaat dari aset yang diwakafkan tersebut selama wäqif tersebut hidup. Wakaf polis asuransi ialah mewakafkan sebagian nilai yang akan diterima jika polis asuransi yang telah dimiliki telah dicairkan. Dalam hal ini, masyarakat yang memiliki polis asuransi dari perusahaan asuransi yang memiliki produk syariah setelah dijadikan polis dan menjadi surat berharga maka manfaatnya atau uang pertanggungannya dan manfaat lainnya itu akan diwakafkan. Potensi yang muncul pasti besar dan banyak namun tergantung penerapan dan pergerakan wakaf wasiat polis asuransi syariah di masa mendatang.

Praktik wakaf wasiat polis asuransi syariah sejak 2012 sudah mulai disosialisasikan dan dipraktikan di beberapa lembaga wakaf, hanya saja baru memiliki legalitas wakaf karena DSN-MUI baru mengeluarkan Fatwa terkait manfaat investasi dan asuransi jiwa syariah pada Oktober 2016. DSN-MUI menjadi acuan bahwa wakaf wasiat polis syariah diperbolehkan dan dilegalkan menurut hukum Islam. Manfaat dari wakaf wasiat polis syariah ini sangat luar biasa dengan memadukan antara wakaf dan asuransi syariah dan ini pun juga hal yang baru di masa sekarang dan mulai berkembang seiring berjalanya waktu dan pemerintah yang mulai

\footnotetext{
2 J. Jairin, "Kajian Sistem Kinerja Keuangan (Operating Financial System) pada Asuransi Syariah dan Asuransi Konvensional Ditinjau dari Perspektif Hukum Islam", Indonesian Interdisciplinary Journal of Sharia Economics (IIJSE), Volume 2, Nomor 2 (2020), 171-89.

${ }^{3}$ https://www.wartaekonomi.co.id/read207639/menilik-pertumbuhan-industri-asuransi-di-indonesia.html diakses pada 1 februari 2020.
} 
medukung wakaf produktif maka solusi yang tepat adalah wakaf wasiat polis asuransi syariah yang secara hukum tepat dan sudah pasti.

Demi menggali potensi dan manfaat wakaf serta pengelolaannya secara produktif digalilah wakaf dari sisi asuransi khususnya dari asuransi syariah dalam hal ini adalah polis asuransi bagi seseorang yang meninggal dunia dan meninggalkan sebagian hartanya hasil dari klaim di lembaga asuransi syariah tertentu. Dari dana klaim tersebut mengandung potensi yang besar saat disalurkan dalam bentuk wakaf selain menjadi amal jariyah bagi si mayit dapat juga bermanfaat bagi umat disertai bentuk pengelolaan yang efektif dan produktif untuk nilai yang jauh lebih besar. ${ }^{4}$

\section{Metode Penelitian}

Penelitian ini termasuk jenis penelitian studi literatur dengan mencari referensi teori yang relevan dengan kasus atau permasalahan yang ditemukan dan juga dari beberapa penelitian terdahulu dan dari internet. Studi literatur adalah cara yang dipakai untuk menghimpun data-data atau sumber-sumber yang berhubungan dengan topik yang diangkat dalam suatu penelitian. Studi literatur bisa didapat dari berbagai sumber, jurnal, buku dokumentasi, internet dan pustaka. Referensi teori yang diperoleh dengan jalan penelitian studi literatur dijadikan sebagai fondasi dasar dan alat utama bagi praktek penelitian ditengah lapangan.

\section{Konsep Dasar Asuransi Syariah}

Definisi asuransi syariah di Indonesia secara baku dijelaskan dalam fatwa DSN-MUI Nomor 21/DSN-MUI/X/2001 tentang Pedoman Umum Asuransi Syariah bahwa asuransi syariah adalah usaha saling melindungi dan tolong-menolong di antara sejumlah orang atau pihak melalui investasi dalam bentuk aset dan atau tabarru' yang memberikan pola pengembalian untuk menghadapi risiko tertentu melalui akad (perikatan) yang sesuai dengan syariah.

Definisi asuransi dalam bahasa Arab disebut al-ta'min, penanggung disebut mu'ammin, sedangkan tertanggung disebut mu'amman lah atau musta'min. Al-ta'min diambil dari kata amana yang artinya memberi perlindungan, ketenangan, rasa aman, dan bebas dari rasa takut. Artinya, bahwa setiap individu suatu masyarakat berada dalam jaminan atau tanggungan masyarakatnya. Setiap orang yang memiliki kemampuan menjadi penjamin dengan suatu kebajikan bagi setiap potensi kemanusiaan dalam masyarakat sejalan dengan pemeliharaan kemaslahatan individu.

Dasar hukum asuransi syariah adalah sumber dari pengambilan hukum praktik asuransi syariah. Karena sejak awal asuransi syariah dimaknai sebagai wujud dari bisnis pertanggungan yang didasarkan pada nilai-nilai yang ada dalam ajaran Islam, yaitu al-Quran dan Hadis, serta pendapat ulama yang tertuang dalam karya-karyanya.

Ayat al-Quran yang mempunyai nilai praktik asuransi, antara lain: ${ }^{5}$

\footnotetext{
${ }^{4}$ Ibid.

${ }^{5}$ Wirdyaningsih, dkk, Bank dan Asuransi di Indonesia (Jakarta: Kencana, 2005), 190.
} 


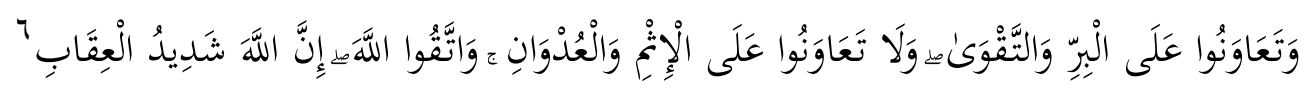

"Dan tolong menolonglah kamu dalam (mengerjakan) kebajikan dan takwa, dan jangan tolong menolong dalam perbuatan dosa dan pelanggaran. Bertakwalah kepada Allah, sesungguhnya Allah sangat berat siksa-Nya".

Ayat al-Māidah ini memuat perintah tolong-menolong antar sesama manusia. Dalam bisnis asuransi, tolong-menolong ini terlihat dalam praktik kerelaan anggota (nasabah) perusahaan asuransi untuk menyisihkan dananya agar digunakan sebagai dana sosial (tabarru').

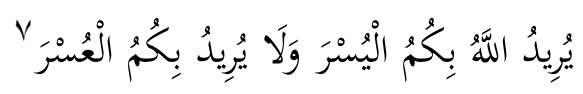

“Allah menghendaki kemudahan bagimu dan tidak menghendaki kesukaran bagimu”.

Ayat di atas menerangkan bahwa kemudahan adalah sesuatu yang dikehendaki olehNya, dan sebaliknya kesukaran adalah sesuatu yang tidak dikehendaki oleh-Nya. Maka manusia dituntut oleh Allah agar tidak mempersulit dirinya sendiri dalam menjalankan bisnis, untuk itu bisnis asuransi merupakan sebuah progam untuk menyiapkan dan merencanakan kehidupan di masa mendatang.

Hadits yang berkaitan dengan asuransi syariah adalah sebagaimana yang diriwayatkan oleh Abu Hurairah:

"Berselisih dua orang wanita dari suku Huzail, kemudian salah satu wanita tersebut melempar batu ke wanita yang lain sehingga mengakibatkan kematian wanita tersebut beserta janin yang dikandungnya. Maka ahli waris dari wanita yang meninggal tersebut mengadukan peristiwa tersebut kepada Rasulullah SAW, maka beliau memutuskan ganti rugi dari pembunuhan terhadap janin tersebut dengan pembebasan seorang budak laki-laki atau perempuan, dan memutuskan ganti rugi kematian wanita tersebut dengan diyat)yang dibayarkan oleh aqilahnya (kerabat dari orang tua laki-laki).

Ijma' para sahabat mengenai aqilah yang dilakukan oleh Khalifah Umar ibn alKhattab. Dengan tidak adanya sahabat yang menentang Khalifah Umar ibn al-Khattab, maka dapat disimpulkan bahwa telah terdapat ijma' di kalangan sahabat Nabi SAW mengenai persoalan ini sehingga melandasi terciptanya asuransi syariah.

Adapun prinsip dasar asuransi syariah adalah pertama, tolong-menolong dengan prinsip tabarru'. Berbeda dengan sistem pembayaran premi pada polis asuransi konvensional, akad asuransi syariah memberlakukan uang nasabah sebagai dana tabarru'. Adapun yang dimaksud dengan dana tabarru' adalah kontribusi seluruh nasabah yang akan diberikan sebagai hibah (pemberian sukarela) pada nasabah lain yang menghadapi risiko. Prinsip asuransi syariah ini juga dikenal sebagai risk sharing antar nasabah. Kedua, investasi dengan prinsip tijärah. Dalam Hadis, Rasulullah SAW melarang akad di mana uang dipakai untuk dana investasi (tijärah) dan sekaligus untuk meraih manfaat perlindungan. Maka dari itu, uang nasabah akan

\footnotetext{
${ }^{6}$ al-Quran, $5: 2$.

${ }^{7}$ Ibid., 2: 185 .
} 
digunakan untuk dua tujuan, yaitu dikumpulkan pada dana tabarru' dan untuk akad tijarah yang nantinya uang nasabah akan diinvestasikan oleh perusahaan asuransi dan dikembalikan setelah akad berakhir. Ketiga, keadilan bagi semua pihak dengan prinsip wakalah bi al-ujrah. Segala akad yang mengatur aktivitas keuangan syariah harus didasari aturan yang adil bagi setiap pihak yang terlibat termasuk pihak perusahaan asuransi sebagai pengelola. Prinsip asuransi syariah ini mengharuskan para nasabah membayar ujrah (upah) dan perusahaan asuransi diberikan amanah menjauhi aktivitas keuangan dari gharär (ketidakjelasan), riba, atau maysir (perjudian). ${ }^{8}$

Adapun asuransi syariah harus dalam prinsip umum syariah yang sesuai dengan fatwa DSN-MUI Nomor: 21/DSN-MUI/X/2001, yaitu:

1. Asuransi syariah (ta'min, takäful atau tadämun) adalah usaha saling melindungi dan tolong menolong di antara sejumlah orang atau pihak melalui investasi dalam bentuk aset dan atau tabarru' yang memberikan pola pengembalian untuk mengahadapi risiko tertentu melalui akad (perikatan) yang sesuai dengan syariah.

2. Akad yang sesuai syariah yang dimaksud pada point 1 di atas adalah yang tidak mengandung gharär (penipuan), maysir (perjudian), riba, zulm (penganiayaan), rishwah (suap), barang haram dan maksiat.

3. Akad tijärah adalah semua bentuk akad yang dilakukan untuk tujuan komersial.

4. Akad tabarru' adalah semua bentuk akad yang dilakukan dengan tujuan kebajikan dan tolong menolong, bukan semata untuk tujuan komersial.

5. Premi adalah kewajiban peserta asuransi untuk memberikan sejumlah dana kepada perusahaan asuransi sesuai kesepakatan dalam akad.

6. Klaim adalah hak peserta asuransi yang wajib diberikan oleh perusahaan asuransi sesuai dengan kesepakatan dalam akad.

Unsur premi pada asuransi syariah terdiri dari:

1. Unsur tabarru' dan tabungan (untuk asuransi jiwa).

2. Unsur tabarru' saja (untuk asuransi kerugian dan term insurance)

Unsur tabarru' pada jiwa perhitungannya diambil dari tabel mortalitas (harapan hidup), yang besarnya tergantung usia dan masa perjanjian. Semakin tinggi usia dan semakin panjang masa perjanjiannya, maka semakin besar pula nilai tabarru'nya. Besarnya premi asuransi jiwa (tabarru') berada pada kisaran 0,75 persen sampai 12 persen.

Beberapa pakar asuransi syariah, seperti M. Billah menyebut premi ini dengan istilah kontribusi (contribution). Billah menghindari istilah tabarru' karena dalam praktiknya pada produk term insurance di asuransi jiwa dan semua produk pada asuransi kerugian terdapat bagi hasil (mudârabah) apabila tidak terjadi klaim, sedangkan tabarru' menurut sebagian pakar syariah tidak dibenarkan adanya harapan pengembalian. ${ }^{9}$

Premi pada asuransi syariah disebut juga net premium karena hanya terdiri dari mortalitas, dan di dalamnya tidak terdapat unsur loading (komisi agen, biaya administrasi, dan lain-lain). Juga tidak mengandung unsur bunga sebagaimana pada asuransi konvensional.

\footnotetext{
8 https://www.prudential.co.id/id/Informasi-untuk-Anda/artikel-asuransi-jiwa/syariah/3-prinsip-dasar-asuransisyariah-yang-wajib-diketahui/ diakses pada 16 Februari 2020.

${ }_{9}^{9}$ Muhammad Syakir Sula, Asuransi Syariah (Life And General) (Jakarta: Gema Insani Press, 2004), 311.
} 
Premi yang dibayar oleh pembeli asuransi tergantung kepada sifat kontrak yang telah dibuat antara perusahaan asuransi dengan tertanggung.

Macam-macam premi antara lain:

1. Premi meningkat (natural premium-increasing premium) adalah pembayaran premi yang semakin lama semakin bertambah besar. Pada waktu tahun permulaan, premi asuransi yang dibayar rendah, tetapi setelah itu, semakin lama semakin bertambah tinggi dari tahun ke tahunnya. Pembayaran premi meningkat setiap tahunnya karena umur pemegang polis bertambah lama bertambah naik (tua) yang berarti resiko meningkat pula, serta kemungkinan untuk meninggal dunia lebih cepat.

2. Premi merata (level premium). Pada level premium besarnya premi yang dilunasi oleh pemegang polis untuk setiap tahunnya sama (merata).

Pada tahun-tahun permulaan, pembayaran preminya lebih besar dari pada natural premium, sedangkan pada tahun-tahun berikutnya pembayaran preminya lebih rendah bila dibandingkan dengan increasing premium.

\section{Konsep Dasar Wakaf}

Menurut Bahasa, wakaf berasal dari waqf yang berarti radi'ah (terkembalikan), altaḥbis (tertahan), al-tasbil (tertawan), dan al-man'u (mencegah). Perkataan wakaf yang menjadi bahasa Indonesia, berasal dari bahasa Arab dalam bentuk mașdar atau kata yang dijadikan kata kerja atau fi'il waqafa. Kata kerja atau fi'il waqafa ini adakalanya memerlukan objek (muta'addi). Dalam perpustakaan sering ditemui sinonim waqf, yaitu habs. Waqafa dan habasa dalam bentuk kata kerja yang bermakna menghentikan dan menahan atau berhenti di tempat. ${ }^{10}$

Dalil yang menjadi dasar disyariatkannya ibadah wakaf adalah:

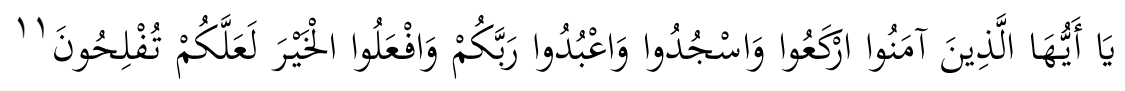

"Hai orang-orang yang beriman, rukuklah kamu, sujudlah kamu, sembahlah Tuhanmu dan perbuatlah kebajikan supaya kamu mendapat kemenangan."

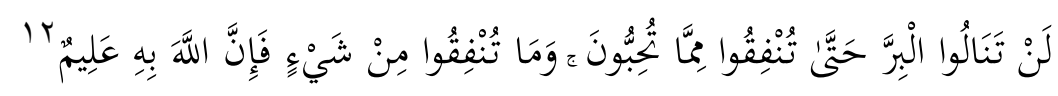

"Kamu sekali-kali tidak sampai kepada kebajikan (yang sempurna), sebelum kamu menafkahkan sehahagian harta yang kamu cintai. Dan apa saja yang kamu nafkahkan maka sesungguhnya Allah mengetahuinya."

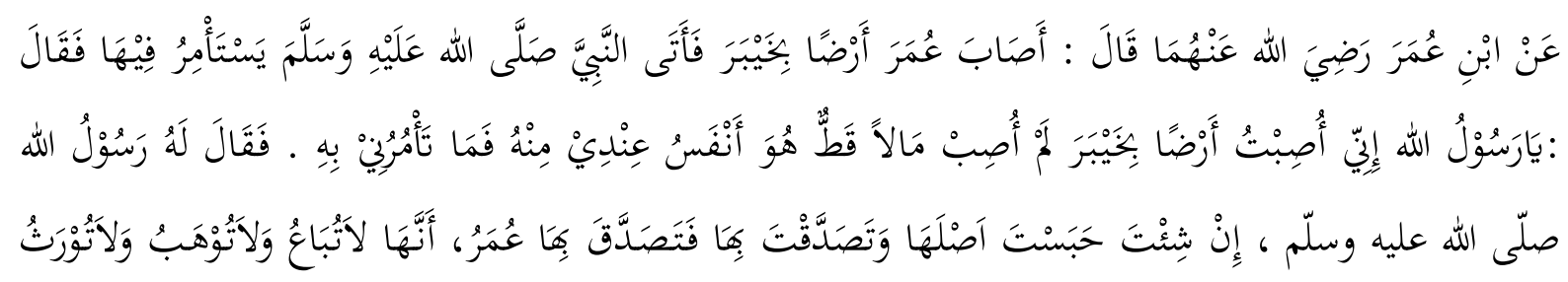

${ }^{10}$ Abdul Halim, Hukum Perwakafan di Indonesia (Ciputat: Ciputat Press, 2005), 6.

${ }^{11}$ al-Quran, 22: 77.

${ }^{12}$ Ibid., 3: 92. 


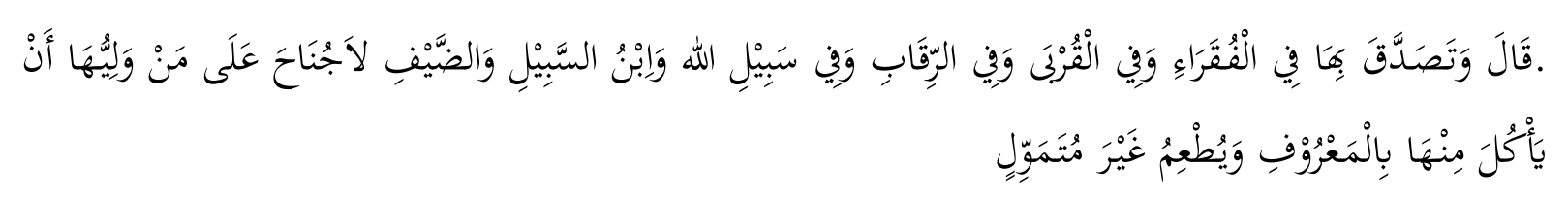

"Dari Ibn Umar ra. berkata bahwa sahabat Umar ra. memperoleh sebidang tanah di Khaibar, kemudian Umar ra. menghadap Rasulullah SAW untuk meminta petunjuk. Umar berkata: "Hai Rasulullah SAW saya mendapat sebidang tanah di Khaibar, saya belum mendapatkan harta sebaik itu, maka apakah yang engkau perintahkan kepadaku?" Rasulullah SAW bersabda: "Bila engkau suka, kau tahan (pokoknya) tanah itu dan engkau sedekahkan (hasilnya)". Kemudian Umar mensedekahkan (tanahnya untuk dikelola), tidak dijual, tidak dihibahkan dan tidak diwariskan. Ibn Umar berkata: "Umar menyedekahkannya (hasil pengelolaan tanah) kepada orang-orang fakir, kaum kerabat, hamba sahaya, sabilillah, ibn sabil dan tamu. Dan tidak dilarang bagi yang mengelola wakaf makan dari hasilnya dengan cara yang baik (sepantasnya) atau memberi makan orang lain dengan tidak bermaksud menumpuk harta”.

Wakaf dinyatakan sah apabila terpenuhi rukun dan syaratnya. Adapun rukun dari Wakaf adalah pertama, orang yang berwakaf (wäqif) dengan syarat mempunyai kecakapan untuk melakukan tabarru', yaitu melepaskan hak milik tanpa imbalan materi, serta baligh, berakal sehat, dan tidak terpaksa. Kedua, sesuatu (harta) yang diwakafkan (mauqüf bih) dengan syarat harta yang bernilai dan tahan lama, dan milik sendiri walaupun hanya sebagian yang diwakafkan atau mushārakah (bercampur dan tidak dapat dipindahkan dengan bagian yang lain). Ketiga, mauqü 'alayh atau tempat berwakaf (yang berhak menerima hasil wakaf itu). Keempat, akad atau șighah (pernyataan atau ikrar wakif), misalnya pernyataan "saya wakafkan ini kepada masjid, sekolah, orang yang tidak mampu dan sebagainya". Tidak perlu qabul (jawab) kecuali yang bersifat pribadi (bukan bersifat umum).

Adapun syarat dari wakaf adalah pertama, wakaf tidak dibatasi dengan waktu tertentu sebab perbutan wakaf berlaku untuk selamanya, tidak waktu untuk waktu tertentu. Jika seseorang mewakafkan kebun untuk jangka waktu sepuluh tahun misalnya, maka wakaf tersebut dipandang batal. Kedua, tujuan wakaf harus jelas, seperti mewakafkan sebidang tanah untuk masjid, mushalla, pesantren, makam dan lainnya. Namun, apabila seseorang mewakafkan sesuatu kepada hukum tanpa menyebut tujuannya, hal itu dipandang sah sebab penggunaan benda-benda wakaf tersebut menjadi wewenang lembaga hukum yang menerima harta-harta wakaf tersebut. Ketiga, wakaf harus segera dilaksanakan setelah dinyatakan oleh yang mewakafkan tanpa digantungkan pada peristiwa yang akan terjadi di masa yang akan datang sebab pernyataan wakaf berakibat lepasnya hak milik bagi yang mewakafkan. Jika wakaf digantungkan dengan kematian yang mewakafkan, ini bertalian dengan wasiat dan tidaklah bertalian dengan wakaf. Dalam pelaksanaan seperti ini, berlakulah ketentuanketentuan yang bertalian dengan wasiat. Keempat, wakaf merupakan perkara yang wajib dilaksanakan tanpa adanya hak khiy $\overline{a r}$ (membatalkan atau meneruskan wakaf yang telah diucapkan) sebab pernyataan wakaf berlaku seketika dan untuk selamanya.

Adapun yang dimaksud dengan harta benda wakaf adalah harta benda dimiliki dan dikuasai oleh wäqif secara sah dan merupakan salah satu unsur penting dalam perwakafan. Undang-Undang Nomor 41 Tahun 2004 tentang wakaf menegaskan bahwa salah satu syarat 
utama yang harus dipenuhi mengenai harta benda wakaf adalah harta benda yang hendak diwakafkan dimiliki dan dikuasai oleh wäqif secara sah.

Dari pengertian di atas dapat dipahami harta benda yang dapat diwakafkan oleh wäqif hanya harta yang nyata-nyata dimiliki dan dikuasai sepenuhnya oleh wäqif secara sah. Seorang wäqif tidak bisa mewakafkan harta yang diperoleh secara sah, akan tetapi tidak dimilikannya atau dikuasai pada saat itu.

Peraturan perundangan perwakafan menegaskan bahwa yang dimaksud dengan benda tidak bergerak tersebut meliputi hak atas tanah, hak atas bangunan, hak atas tanaman, hak milik atas satuan rumah susun dan benda tidak bergerak lain. Sesuai ketentuan peraturan perundangan-undangan perwakafan, bahwa hak atas tanah yang menjadi objek wakaf tersebut adalah hak atas tanah sesuai dengan peraturan perundangan baik sudah maupun yang belum terdaftar. Hak-hak yang sudah terdaftar, misalnya hak milik, hak guna bangunan, hak guna usaha, hak pakai. Sedangkan yang belum terdaftar, misalnya hak milik adat, hak atas tanah yang dikuasai langsung oleh negara yang dimiliki seseorang. Selain hak atas tanah, hak yang dapat diwakafkan adalah hak atas bangunan atau bagian bangunan yang berdiri di atas tanah sebagaimana dikemukakan di atas. Misalnya seseorang memiliki beberapa petak toko di suatu pusat perbelanjaan. Pemilik toko tersebut dapat mewakafkan satu petak atau beberapa petak dari bangunan toko yang dimilikinya itu.

Selanjutnya yang dapat diwakafkan oleh wāqif adalah tanaman dan benda lain yang berkaitan dengan tanah. Dalam hal ini yang diwakafkan adalah berupa pohon atau pokok tanaman yang berada dan tumbuh di atas tanah, sedangkan tanahnya tidak diwakafkan. Misalnya wakaf pohon kelapa, wakaf pohon sawit, wakaf pohon durian dan lain sebagainya. Wakaf pohon ini banyak ragamnya, misalnya dengan cara setiap panen kelapa, hasil penjualan buah kelapa dari pokok kelapa yang diwakafkan itu diserahkan kepada pengurus masjid. Hasil penjualan panen buah kelapa tersebut terus diserahkan selama pokok kelapa itu berbuah atau selama diperlukan.

Selain benda tidak bergerak, benda yang bergerak juga dapat diwakafkan, asalkan benda tersebut tidak habis karena dikonsumsi. Pasal 16 ayat (3) Undang-Undang Wakaf menegaskan benda-benda bergerak yang dapat diwakafkan adalah berupa uang, logam mulia, surat berharga, kendaraan, hak atas kekayaan intelektual, hak sewa, dan benda bergerak lain sesuai dengan ketentuan syariah dan peraturan perundang-undangan yang berlaku. ${ }^{13}$

Wakaf berupa benda bergerak misalnya wakaf uang. Wakaf uang ini kemudian diinvestasikan dan hasil investasi yang diperoleh dipergunakan sesuai dengan kehendak wäqif, misalnya untuk membantu fakir miskin, biaya pendidikan dan lain-lain. Wakaf uang ini potensinya sangat besar, sebab selain wäqif tidak mesti kaya (karena uang lima ratus rupiah pun dapat diwakafkan) juga lebih mudah untuk diinvestasikan. Dengan mudahnya untuk diinvestasikan tentu akan lebih cepat untuk menghasilkan. Kalau wakaf sudah menghasilkan maka wäqif akan lebih cepat untuk memperoleh aliran pahala.

Objek wakaf berupa logam mulia, misalnya berupa koin emas atau barang-barang perhiasan lainnya. Sedangkan objek wakaf berupa surat berharga, misalnya berupa saham di perusahaan. Pada saat perusahaan membagi deviden atas saham-saham, maka dividen atas

\footnotetext{
${ }^{13}$ Lihat pasal 15 dan 16 Undang-Undang Nomor 41 Tahun 2004.
} 
saham yang telah diwakafkan dipergunakan sesuai dengan tujuan yang dikemukakan oleh wäqif pada saat berwakaf.

Benda bergerak lainnya yang dapat diwakafkan adalah kendaraan, misalnya pemilik kendaraan mewakafkan kendaraan yang dimilikinya untuk transportasi anak-anak panti asuhan. Selanjutnya benda bergerak yang dapat diwakafkan adalah hak atas kekayaan intelektual (HAKI), misalnya seorang pengarang buku mewakafkan hak cipta yang dimilikinya atas sebuah buku dan selanjutnya royalti yang diperoleh dari penjualan buku tersebut dimanfaatkan sesuai dengan tujuan wakaf oleh pengarang buku yang telah mewakafkan haknya.

Selain benda-benda bergerak yang dikemukakan di atas, yang digolongkan kepada benda bergerak yang dapat diwakafkan adalah hak sewa. Misalnya wāqif menyewa sebuah rumah selama dua tahun kemudin hak sewa selama dua tahun tersebut diwakafkan untuk kepentingan tempat tinggal pelajar dan mahasiswa yang sedang menuntut ilmu. Begitu juga benda-benda bergerak lainnya yang dapat dipergunakan sesuai dengan ketentuan syariah dan peraturan perundang-undangan yang berlaku di Indonesia.

Ada beberapa jenis wakaf di antaranya adalah pertama, wakaf ahli, yaitu wakaf yang ditunjukan pada orang orang tertentu. Kedua, wakaf khairi, yaitu wakaf yang digunakan untuk urusan keagamaan atau kemasyarakatan. Wakaf khairi lebih banyak manfaatnya bukan hanya untuk wäqif tapi juga untuk masyarakat umum. Hal ini lah yang melatar belakangi munculnya produk wakaf wasiat polis di mana nantinya dana akan dikelolala oleh lembaga wakaf untuk produktif seperti pembangunan tempat sekolah, rumah sakit, dan sebagainya.

Pengelola akan mengelola dana dari wäqif untuk produktif melalui lembaga wakaf. Di Indonesia pengelolaan wakaf dilakukan oleh badan atau lembaga khusus yang disebut Badan Wakaf Indonesia yang juga diatur dalam undang undang Nomor 41/2004. BWI ini nantinya yang mengelola wakaf agar produktif dan bermanfaat bagi semua orang.

\section{Wakaf Wasiat Polis Asuransi Syariah}

Permasalahan kemiskinan merupakan sebuah fenomena yang terus menghantui, apalagi di negara yang mayoritas Islam khususnya Indonesia. Kemiskinan sudah menjadi budaya di dalam masyarakat yang hampir tidak ada jalan keluarnya. Kebijakan-kebijakan pemerintah dalam rangka mengatasi problem sosial masyarakat dan tuntutan kesejahteraan di negeri ini tidak berujung pada solusi. Miris kiranya jika kita hanya bisa menutup mata tanpa memperdulikan problem sosial masyarakat di negeri ini, salah satu kebijakan yang menjadi perhatian dan harus digalakkan dalam membantu mengatasi problem tersebut adalah wakaf produktif. Mayoritas masyarakat memahami wakaf masih sebatas tradisional, yaitu masih berupa benda-benda fisik yang tidak bergerak, seperti tanah, bangunan yang diperuntukkan untuk masjid, pendidikan, pekuburan, pondok pesantren dan lain sebagainya. Pemanfaatan benda wakaf seperti ini masih berbentuk pada hal-hal yang bersifat fisik, sehingga tidak memberikan dampak ekonomi yang bertujuan untuk mensejahterakan umat. Perlu adanya sosialisasi dalam merubah paradigma masyarakat yang masih tradisional bahwa wakaf selain berdimensi keagamaan, ekspektasi wakaf di bidang sosial ekonomi perlu digalakkan untuk tujuan memberikan manfaat ekonomi bagi masyarakat. Pada dasarnya, wakaf itu produktif 
dalam arti harus menghasilkan karena wakaf dapat memenuhi tujuannya jika telah menghasilkan di mana hasilnya dimanfaatkan sesuai dengan mauqü alayh.

Perkembangan asuransi syariah di Indonesia sangatlah pesat dan bervariasi. Masyarakat Indonesia sedikit banyak mulai terasa meskipun di tahun 2020 ini diterjang isu Jiwaseraya di mana telah mencoreng nama asuransi di Indonesia termasuk asuransi syariah namun asuransi syariah tetap eksis sebagai asuransi yang aman dan tenteram karena memang inilah yang masyarakat butuhkan bahkan meningkat dari tahun ke tahun. Banyak yang menilai bahwa para pegiat asuransi syariah menargetkan asuransi syariah tumbuh dan optimistis memasang target pertumbuhan aset sebesar 14,76 persen pada 2019 dari tahun sebelumnya. Hal ini dipicu kondisi sektor syariah yang tengah berkembang di Indonesia.

Berdasarkan data Otoritas Jasa Keuangan, aset asuransi syariah mencapai 41,96 triliun rupiah pada 2018. Aset tersebut berasal dari asuransi jiwa syariah senilai 34,47 triliun rupiah, asuransi umum syariah 5,62 triliun rupiah, dan reasuransi syariah 1,86 triliun rupiah. Artinya, aset pada tahun ini setidaknya ditargetkan menembus 48,15 triliun rupiah. ${ }^{14}$ Dengan berbagai cara yang sudah dilakukan harusnya mampu meningkatkan pertumbuhan asuransi syariah yang ada di Indonesia ini cara terbaik untuk melakukan atau mempromosikan agar asuransi syariah adalah tidak lain adalah kemaslahatan umat bukan tipuan di mana asuransi ini harus bermanfaat terhadap perorangan maupun masyarakat luas. Dengan itu asuransi syariah dapat dikenal dan dijadikan sebagai hal kebutuhan masyarakat di Indonesia yang mayoritas muslim namun tidak menutup kemungkinan non muslim juga bertransaksi melalui asuransi syariah jika asuransi syariah terbukti unggul dan manfaatnya luar biasa.

Asuransi syariah juga mendapat pengawasan dari OJK dengan hal ini juga memperkuat anggapan bahwa asuransi syariah aman dan relatif menguntungkan. Pengawasan yang dilakukan oleh OJK didasarkan atas kepatuhan perusahan asurani reasuransi syariah terhadap peraturan perundang-undangan. Ada hal yang menarik juga di mana mulai tahun 2015 asuransi syariah pengawasan didasarkan pada risiko (risk based supervision). Pengawsan ini merupakan pengawasan ke depan yang lebih menitikberatkan pada identifikasi masalah secara dini dan pengambil pengawasan yang tepat. ${ }^{15}$ Tentu hal ini membuat customer lebih percaya diri.

Wakaf adalah bentuk kedermawanan dalam Islam yang memberikan manfaat berkelanjutan bagi masyarakat sehingga menjanjikan pahala yang tidak terputus. wakaf wasiat memiliki pengertian suatu perencanaan wakaf dengan mewariskan secara legal. Sebagian dari kepemilikan aset wäqif ketika yang bersangkutan meninggal dunia namun tetap dapat menikmati manfaat dari aset yang diwakafkan selama wäif tersebut hidup. ${ }^{16}$

Polis Asuransi adalah surat perjanjian antara pihak tertanggung dan pihak penanggung. Kemudian, polis ini mengandung segala hal terkait asuransi yang disetujui. Kedua belah pihak wajib untuk mengetahui isi dari asuransi ini termasuk pengertian dasar, peraturan, ketentuan dan lain-lain. Polis asuransi inilah yang akan menjadi bukti dan alat untuk mengajukan asuransi dari pihak tertanggung. Adapun pengertian dari wakaf wasiat polis yaitu

\footnotetext{
14 https://www.cnnindonesia.com/ekonomi/20190517200737-78-395891/industri-asuransi-syariah-optimistisaset-tumbuh-1476-persen diakses pada 2 Februari 2020.

${ }^{15}$ Mohamad Toha, et al, Bank dan Lembaga Keuangan Syariah (Malang: Literasi Nusantara, 2019), 126.

16 Mohammad Luthfillah Habibi, dkk, "Membangun Integrated Takaful dan Wakaf Model dalam Upaya Meningkatkan Kemanfaatan Pemegang Polis”, Jurnal Al-Uqud, Volume 1, Nomor 2 (2017), 139-155.
} 
mewakafkan sebagian dari apa yang akan didapatkan oleh peserta asuransi jika peserta asuransi mengalami risiko.

Wakaf wasiat polis gabungan dari wakaf dan asuransi merupakan inovasi produk baru dari asuransi syariah yang berkerjasama dengan lembaga wakaf. Namun potensi wakaf wasiat polis sangat besar. Potensi wakaf wasiat polis asuransi syariah dapat berkembang dan mampu menambah sumbangan wakaf yang ditargetkan Badan Wakaf Indonesia, hal ini terlihat dari perkembangan lembaga keuangan syariah. Konsep wakaf wasiat polis diatur oleh dua lembaga, yaitu perusahaan asuransi syariah dan lembaga wakaf. Perusahaan asuransi syariah berperan sebagai pengelola administrasi dan kontribusi dana polis asuransi peserta. Ketika peserta mengalami risiko atau sudah masa jatuh tempo maka manfaat wakaf dari manfaat asuransi dan manfaat investasi akan diserahkan oleh lembaga yang sudah ditunjuk. Walapun masih baru, wakaf wasiat asuransi syariah ini sangat sesuai jika diterapkan untuk kemajuan umat, Asosiasi Asuransi Syariah Indonesia (AASI) menilai wakaf asuransi syariah berpotensi besar untuk berkembang di Indonesia. Hal itu mengingat Indonesia yang merupakan negara mayoritas muslim terbesar di dunia.

Wakaf wasiat polis asuransi syariah merupakan wakaf berupa polis asuransi syariah di mana nilai investasinya dan atau manfaat asuransinya diwakafkan oleh tertanggung utama, tentu saja dengan sepengetahuan ahli waris. Wakaf asuransi syariah bertujuan untuk pemanfaatan asuransi dengan berinvestasi melalui lembaga pengelola wakaf yang nantinya memiliki hasil dan manfaat, kemudian manfaat tersebut dapat digunakan untuk kemaslahatan umat.

Data dari Badan Wakaf Indonesia (BWI) menyebutkan potensi wakaf di Indonesia mencapai angka 180 triliun rupiah. Bahkan, berdasarkan data Bank Indonesia, sektor sosial Islam yang mencakup sistem wakaf memiliki potensi sekitar 217 triliun rupiah (atau setara dengan 3,4 persen PDB Indonesia) sehingga dapat memainkan peran yang sangat penting untuk mempercepat pembangunan ekonomi dan mendukung stabilitas keuangan. Jadi wakaf asuransi syariah ini akan mengalami pertumbuhan yang baik dalam industri asuransi. Hal ini disebabkan produk wakaf asuransi merupakan salah satu produk yang spesifik dan hanya berlaku di asuransi syariah. ${ }^{17}$

DSN-MUI melalui fatwanya Nomor 106/DSN-MUI/X/2016 tentang wakaf manfaat asuransi dan manfaat investasi pada asuransi jiwa syariah memiliki ketentuan terkait wakaf, yaitu $^{18}$ pertama, ketentuan wakaf manfaat asuransi, yaitu pihak yang ditunjuk untuk menerima manfaat asuransi menyatakan janji yang mengikat (al-wa'd al-mulzim) untuk mewakafkan manfaat asuransi; manfaat asuransi yang boleh diwakafkan paling banyak 45 persen dari total manfaat asuransi; semua calon penerima manfaat asuransi yang ditunjuk atau penggantinya menyatakan persetujuan dan kesepakatannya; dan ikrar wakaf dilaksanakan setelah manfaat asuransi secara prinsip sudah menjadi hak pihak yang ditunjuk atau penggantinya. Kedua, ketentuan wakaf manfaat investasi, yaitu manfaat investasi boleh diwakafkan oleh peserta asuransi; dan kadar jumlah manfaat investasi yang boleh diwakafkan paling banyak sepertiga dari total kekayaan dan atau tirkah kecuali disepakati lain oleh semua

17 https://nasional.tempo.co/read/1232468/wakaf-asuransi-syariah-fitur-potensial-di-indonesia/full\&view=ok diakses pada 3 Februari 2020.

${ }^{18}$ https://dsnmui.or.id/ diakses pada 16 Februari 2020. 
ahli waris. Ketiga, ketentuan ujrah terkait dengan produk wakaf, yaitu ujrah tahun pertama paling banyak 45 persen dari kontribusi reguler; dan akumulasi ujrah tahun berikutnya paling banyak 50 persen dari kontribusi reguler.

Dari ketentuan tersebut menunjukan bahwa besaran wakaf wasiat polis asuransi menjadi terbatas tidak bisa seluruhnya, yaitu maximal 45 persen untuk wakaf pada manfaat asuransi serta maximal 1/3 dari manfaat investasi asuransi jiwa syariah, kecuali disepakati oleh para ahli waris. Hal ini yang menjadi rambu-rambu dari pihak DSN-MUI mengenai praktik wakaf wasiat polis asuransi syariah tersebut mengingat praktik wakaf ini sudah terlebih dahulu dikenal di masyarakat sebelum keluarnya aturan fatwa DSN-MUI.

Dalam asuransi syariah pada umumnya digunakan untuk hal-hal yang sangat sarat dengan nuansa bisnis atau investasi. Pada dasarnya, secara umum konsepnya hampir sama dengan konsep takâful dengan model saving. Hanya saja pada bagian savingnya lebih dialokasikan untuk wakaf. Sebagai contoh (pada model takäful dengan konsep mudärabah atau wakalah bi al-ujrah) ketika nasabah membayar premi, maka premi tersebut akan diberlakukan menjadi tiga alokasi, yaitu 50 persen untuk ujrah yang dialokasikan untuk operasional perusahaan, 50 persen untuk tabarru', dana tolong-menolong yang dialokasikan kepada nasabah yang terkena musibah (klaim), dan 50 persen untuk saving milik peserta dan sepenuhnya akan dikembalikan ke peserta beserta hasil investasinya.

Sedangkan pada konsep wakaf wakalah distribusi preminya adalah hampir sama kecuali pada sisi savingnya saja yang berubah menjadi wakaf, yaitu 50 persen untuk ujrah yang dialokasikan untuk operasional perusahaan, 50 persen untuk tabarru', dana tolong menolong yang dialokasikan kepada nasabah yang terkena musibah (klaim), dan 50 persen untuk wakaf yang diwakafkan untuk kemaslahatan umat (tidak kembali kepada nasabah). Dana wakaf yang diwakafkan sama sekali tidak boleh digunakan untuk biaya operasional, biaya klaim atau apapun terkait dengan operasional perusahaan asuransi syariah.

Jangka waktu wakaf wasiat polis asuransi pada dasarnya berakhir bila telah tercapai tujuan dari akad tersebut. Namun, selain itu ada sebab lain yang dapat membuat suatu akad berakhir meskipun tujuannya belum tercapai. Para ulama fikih menetapkan sebab-sebab itu sebagai berikut. Pertama, berakhirnya masa berlaku akad apabila akad tersebut memiliki tenggang waktu. Kedua, dibatalkan oleh para pihak yang berakad apabila akad itu sifatnya mengikat dan dapat dibatalkan. Ketiga, akad yang telah sah dan mengikat dianggap berakhir jika akad itu dinyatakan fasad, berlakunya syarat khiyär (dapat memilih meneruskan akad atau tidak), atau akad itu tidak dilaksanakan oleh salah satu pihak. Keempat, salah satu pihak dalam akad meninggal dunia. Dalam hal ini, menurut ulama fikih tidak semua akad berakhir dengan adanya kematian salah satu pihak.

Sebagaimana yang diketahui berakhirnya wakaf wasiat ini yaitu jika polis asuransinya telah jatuh tempo atau telah mendapatkan klaim. Dan benda-benda yang dipertukarkan seperti itu pula harus tertentu jangka waktunya. Jika waktu merupakan bagian dari akad maka akad itu tidak sah jika jangka waktunya tidak diketahui. Dalam hal ini termasuk transaksi yang dipengaruhi waktu, maka harus ditentukan jangka waktunya. Jika waktunya tidak ditentukan, para ulama membagi asuransi ke dalam asuransi atas individu dan asuransi atas benda. Ada juga bentuk asuransi yang lain yang disebut asuransi pertanggungjawaban, dan ini dengan sendirinya merupakan masalah fikih. Asuransi atas benda adalah seperti asuransi atas 
kendaraan, asuransi atas barang-barang dagangan, asuransi kebakaran dan sebagainya. Apabila jangka waktu asuransi-asuransi ini tertentu, maka tidak ada masalah. Demikian pula dalam sebagian asuransi atas individu, seperti asuransi kesehatan, dengan terbatasnya jangka waktu adalah tidak masalah. Nasabah memberikan pembayaran bulanan atau tahunan atas jaminan dari perusahaan asuransi dan apabila dia jatuh sakit selama jangka waktu yang tertentu ini maka perusahaan asuransi itu akan memberikan uang sejumlah tertentu atau biaya pengobatan. Demikian pula asuransi atas kehilangan pekerjaan, maka nasabah setuju untuk memberikan pembayaran bulanan atau tahunan atas jaminan dari perusahaan asuransi yang akan membayarkan sejumlah tertentu apabila muncul sesuatu yang menyebabkan kehilangan pekerjaan.

\section{Kesimpulan}

Wakaf wasiat polis asuransi syariah merupakan inovasi baru dari perusahaan asuransi syariah dengan lembaga wakaf. Wakaf wasiat polis asuransi syariah ini merupakan bentuk lain dari wakaf pada umumnya yang menggunakan polis sebagai objek untuk diwakafkan. Wakaf ini mempunyai potensi yang besar di Indonesia. Wakaf wasiat adalah suatu perencanaan wakaf dengan mewasiatkan secara legal sebagian dari kepemilikan aset wäqif ketika yang bersangkutan meninggal dunia namun tetap dapat menikmati manfaat dari aset yang diwakafkan tersebut selama wäqif tersebut hidup. Wakaf Polis Asuransi ialah mewakafkan sebagian nilai yang akan diterima jika polis asuransi yang telah dimiliki telah dicairkan. Dalam hal ini, masyarakat yang memiliki polis asuransi dari perusahaan asuransi yang memiliki produk syariah setelah dijadikan polis dan menjadi surat berharga maka manfaatnya atau uang pertanggungannya dan manfaat lainnya itu akan diwakafkan. Potensi yang muncul pasti besar dan banyak namun tergantuk penerapan dan peregerakan wakaf wasiat polis asuransi syariah di masa mendatang

\section{Daftar Rujukan}

Choiriyah, "Wakaf Produktif dan Tata Cara Pengelolaanya", Islamic Banking, Volume 2, Nomor 2 (Februari 2017).

Habibi, Mohammad Luthfillah, et al. "Membangun Integrated Takaful dan Wakaf Model dalam Upaya Meningkatkan Kemanfaatan Pemegang Polis", Jurnal Al-Uqud, Volume 1, Nomor 2 (2017).

Halim, Abdul. Hukum Perwakafan di Indonesia. Ciputat: Ciputat Press, 2005.

Jairin, J. "Kajian Sistem Kinerja Keuangan (Operating Financial System) pada Asuransi Syariah dan Asuransi Konvensional Ditinjau dari Perspektif Hukum Islam”, Indonesian Interdisciplinary Journal of Sharia Economics (IIJSE), Volume 2, Nomor 2 (2020).

Sula, Muhammad Syakir. Asuransi Syariah (Life And General). Jakarta: Gema Insani Press, 2004.

Toha, Mohamad, et al. Bank dan Lembaga Keuangan Syariah. Malang: Literasi Nusantara, 2019.

Wirdyaningsih, et.al. Bank dan Asuransi di Indonesia. Jakarta: Kencana, 2005.

https://www.industry.co.id/read/62257/perkembangan-industri-asuransi-syariahmembanggakan-di-tahun-2019 
http:// www.wakafalazhar.or.id/ produk/9- Wakaf+Wasiat+Polis+Asuransi/

https://www.wartaekonomi.co.id/read207639/menilik-pertumbuhan-industri-asuransi-diindonesia.html

https://www.prudential.co.id/id/Informasi-untuk-Anda/artikel-asuransi-jiwa/syariah/3-prinsipdasar-asuransi-syariah-yang-wajib-diketahui/

https://nasional.tempo.co/read/1232468/wakaf-asuransi-syariah-fitur-potensial-diindonesia/full\&view $=$ ok 